\title{
Solar Energy for a Traditional Coastal Fishing Platform
}

\author{
Sunaryo $^{1} \cdot$ Aldy Syahrihaddin $^{2} \cdot$ Pradhana Shadu Imfianto $^{2}$
}

Received: 12 October 2017 / Accepted: 20 August 2018 / Published online: 21 May 2019

(C) The Author(s) 2019

\begin{abstract}
In order to introduce clean environment and sustainable energy to traditional coastal fishing community, the objective of this study is to encourage the Indonesian traditional coastal fishing community to use green and renewable energy in their fishing activities. Introducing solar power as the main source of energy for fish-attracting lights and boat propulsion can reduce the use of fossil fuels, and sustain clean and healthy environment. As the world's largest archipelago, Indonesia accounts for a high percentage of traditional fishing communities spread out along its islands. This fishing communities use various traditional fishing boats, and platforms. The fishing platforms are usually made of bamboo and placed on top of supporting structures on the seabed. Diesel electric generators are used to obtain electricity needed for lighting to attract the fish at night, and as the source of power for lifting the fishing net. The structure and fuel used are neither environmentally friendly nor clean; thus, an innovation is introduced. Traditional fishing practices using a fishing platform were studied, including the common size of the platform and the power needed for the fishing light. Based on the gathered information, this study proposes a catamaran vessel with a special top structure designed for fish lifting outfitting, and equipped with photovoltaic solar cells as the energy source for the fishing lights and vessel propulsion. Through this innovative break through, the vessel can be moved to the shore and will not be a threat to ship navigation and the environment. Furthemore, powered by clean and sustainable energy, the vessel can be directed to the best fishing ground.
\end{abstract}

Keywords Catamaran $\cdot$ Fishing lights $\cdot$ Fishing platform $\cdot$ Lifting net $\cdot$ Photovoltaic panel $\cdot$ Solar energy

\section{Introduction}

As the world's largest archipelago, consisting of more than 17000 islands, Indonesia accounts for a high percentage of traditional fishing communities that are spread out across the

\section{Article Highlights}

- Abundant clean and sustainable solar energy in the tropical country such as Indonesia can be benefited as substitution to fossil fuel for coastal fishing activities.

- Electricity obtained from photovoltaic solar cells is used for fishing lights, vessel propulsion, and fishing net lifting winch.

- HDPE catamaran boat is introduced as alternative to the bamboo fishing platform.

\section{Sunaryo}

naryo@eng.ui.ac.id

1 Indonesian Maritime Center, Universitas Indonesia, Depok 16424, Indonesia

2 Naval Architecture and Marine Engineering Study Program, Universitas Indonesia, Depok 16424, Indonesia country and use various traditional fishing boats and fishing tools such as purse seins, gill nets, and trawls (Olaniyan 2015). Fishing platforms are also used widely. The fishing platforms are typically made of bamboo and attached to supporting structures standing on the seabed (Sudirman and Mallawa 2004). Fishing activities are carried out at night when the sea environment is dark, so that schools of coastal pelagic fish such as Decapterus russelli (scads), Selar crumenophthalmus (big-eye scad), Rastrelliger kanagurta (Pacific mackerel), Sardinella gibbosa (sardine), and Amblygaster sirm (spotted sardine) (Sadhotomo 2007) can be attracted to the platform by certain colors and bright lights (Solomon 2016). In some remote places, kerosene pressure lanterns were traditionally used as fishing lights, but in the past 20 years, these were "modernized" and replaced by electric lamps. Diesel electric generators are now used to produce the electricity needed for lighting and as the power source for lifting the fishing net. The structure and fuel used are neither environmentally friendly nor clean. The platforms laid on the ship navigation lanes sometimes become a threat to navigation systems, and may endanger passing ships as well as fishermen working 


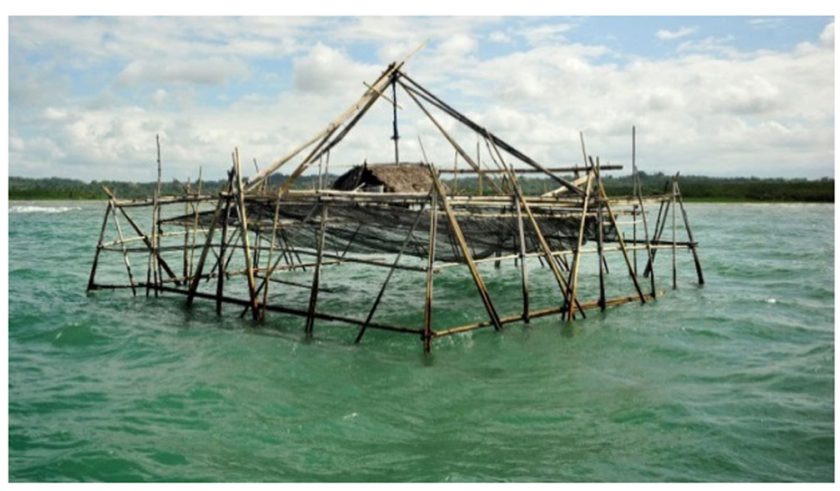

Fig. 1 Traditional bamboo fishing platform

on the platform. When the platforms are no longer useful due to age and decay, they are simply abandoned in their locations, eventually generating debris that is difficult to detect by passing ships. The fuel used for the electric generator sometimes drips into the sea and pollutes the surrounding area. Owing to these considerations, this study proposes an asymmetrical catamaran as an alternative to the bamboo structure; this catamaran is equipped with solar panels for a more environmentally friendly source of energy to be used on the fishing platform. Figure 1 shows a picture of the traditional bamboo fishing platform (Michelino 2010).

\section{Materials and Methods}

The asymmetrical catamaran is introduced, so that the fishing platform can be moved to the shore in the daytime. As fishing activities are conducted at night, the sea becomes cleaner and the platform does not obstruct the ship navigation lanes. The catamaran is constructed using high-density polyethylene (HDPE), which can be recycled when the boat is no longer in use. As the substitute to fossil fuels, solar energy is used for the fishing lights, boat propulsion, and net lifting winch. This energy source is feasible because Indonesia is located on the equator, and benefits from sunshine throughout year.

Table 1 Main particulars of asymmetrical catamaran fishing platform

\begin{tabular}{lr}
\hline Length overall(m) & 14.50 \\
Breadth total(m) & 6.40 \\
Distance between hulls(m) & 2.70 \\
Height $(\mathrm{m})$ & 2.04 \\
Draft $(\mathrm{m})$ & 0.68 \\
Displacement(t) & 6.08 \\
Operational speed(m/s) & 5.00 \\
\hline
\end{tabular}

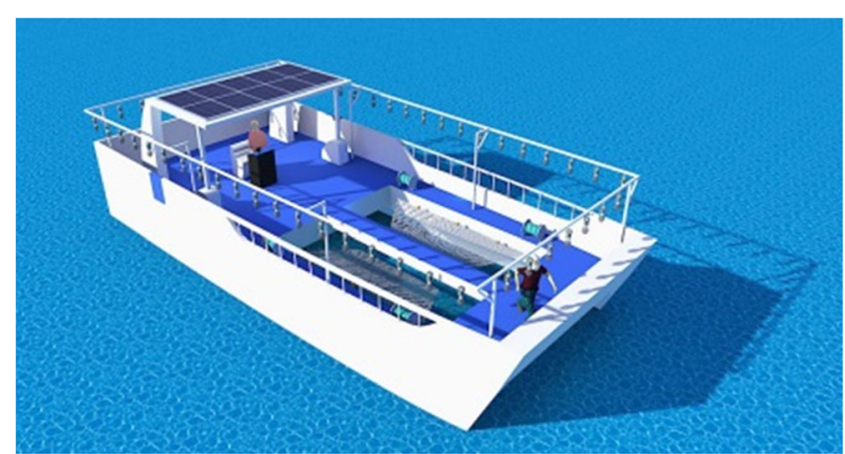

Fig. 2 Design of proposed platform

\subsection{Catamaran Fishing Platform}

The use of an asymmetrical catamaran (Setyawan et al. 2010) as the fishing platform is advantageous because this vessel has less resistance due to wave interference from the hulls (Jamaluddin et al. 2012; Nursal et al. 2017), and provides easier access for the fishing net to be lowered or lifted between the two hulls.

As the material for the proposed platform, HDPE has outstanding characteristics (Tideman 2015), such as good buoyancy, lighter density than water; resistance to corrosion, marine growth, as well as UV; great flexibility in production; low carbon footprint; $100 \%$ recyclability, and being easy to repair.

After considering operational aspects, such as the existing fishing platform, dimenssions of the fishing net, distance of the fishing ground from the shore, and several catamaran references (Sohn et al. 2013; Utama et al. 2013), we present the particulars of the proposed asymmetrical catamaran fishing platform in Table 1, and illustrate the design in Fig. 2.

\subsection{Source of Energy}

Solar energy is used to obtain clean and sustainable energy for the propulsion of the catamaran platform, operation of net

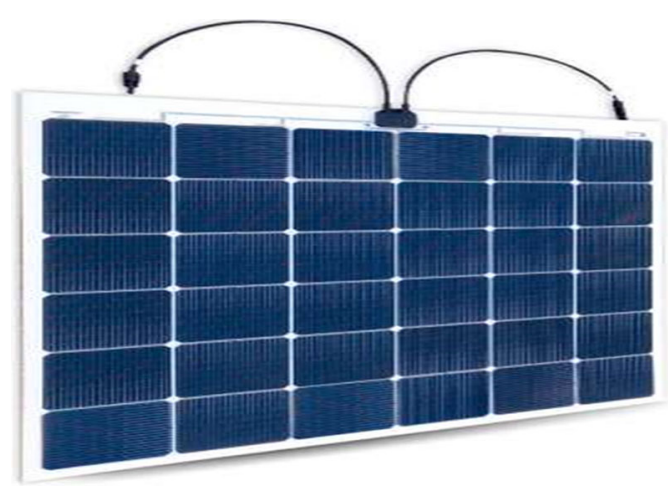

Fig. 3 PV panel 
Table 2 PV panel specifications

\begin{tabular}{lc}
\hline Power $(\mathrm{W})$ & 156 \\
Weight $(\mathrm{kg})$ & 2.3 \\
Length $(\mathrm{mm})$ & 1046 \\
Width $(\mathrm{mm})$ & 996 \\
Thickness $(\mathrm{mm})$ & 2 \\
No. of cells & 36 \\
Open circuit voltage $\left(V_{\mathrm{oc}} / \mathrm{V}\right)$ & 23 \\
Maximum power voltage $\left(V_{\mathrm{mp}} / \mathrm{V}\right)$ & 18 \\
Short circuit current $\left(I_{\mathrm{sc}} / \mathrm{A}\right)$ & 9 \\
Maximum power current $\left(\mathrm{I}_{\mathrm{pm}} / \mathrm{A}\right)$ & 8.6 \\
\hline
\end{tabular}

winch, and lightings for attracting fish and working. Photovoltaic (PV) panels are used to tap the energy from sunshine. Monochrystalline-type SP 156 Q/Mon flex cell PV panels are used for this purpose (as shown in Fig. 3), with the specifications shown in Table 2.

To convert the solar energy into electric power, MPPT Victron-type solar charge controllers as shown in Fig. 4 are used. The specifications are shown in Table 3 (Victron Energy 2017).

\subsection{Energy Estimation}

The electric power needed to operate all the equipment on the platform should be calculated to determine the number of PV panels to be installed on the platform as the source of energy. The equipment that need electric power are lights for fishing and working purposes, net winch for lifting the net to the platform when the catch is full, and propulsion of the platform from the shore to the fishing ground and vice versa.

To determine the energy needed for the electrical equipment, the following steps are conducted: (1) identifying the equipment and its energy consumption, (2) determining the operational duration of each equipment, (3) determining the total energy required, and (4) categorizing every electrical equipment and summarizing its total energy consumption based on each category. The formula to estimate the required energy is as follows:

Total energy $E=p \times n \times t$
Table 3 Solar charge controller specifications

\begin{tabular}{ll}
\hline Type & Step down \\
\hline Battery type & $\mathrm{Pb}$ \\
Battery voltage $(\mathrm{V})$ & 12 and 24 \\
Maximum panel power $(12 \mathrm{~V} / \mathrm{W})$ & 700 \\
Maximum panel power $(24 \mathrm{~V} / \mathrm{W})$ & 1400 \\
Minimum voltage & $>$ battery voltage \\
Maximum current(A) & 50 \\
\hline
\end{tabular}

where $E$ is total energy (Wh), $t$ is operational duration (h), $P$ is power $(\mathrm{W})$, and $n$ is the number of equipment.

\subsubsection{Lighting}

Three types of lightings are used on the platform namely, fishing, cabin, and working lights. Ambience LED lamps are used as fishing lights, whose color (white, red, and green) can be changed in accordance with the fishing sequences without changing the bulbs; these lamps consume considerably low electric power (Aditia 2017; Shen and Huang 2012; Solomon 2016). LED flood lights are used as working lights when the net has been lifted to provide sufficient light for the fishermen to transfer the fish from the net into the fish holds or boxes. Ordinary cabin LED bulbs are used as cabin light (Susanto et al. 2017). The power needed for the lighting is estimated by summing the total number of lights multiplied by the power used on each type of light.

\subsubsection{Net Winch}

A net winch is used solely for lifting the net from under the sea when the net has been filled with a sufficient amount of fish. Two winches, as shown in Fig. 5, are employed for the lifting operation, one on each side of the inner hull of the catamaran. Ropes are tied to the upper edges of the net and rolled on the winch drum (Regnu Rama Das 2017). The winch itself is run through an electric motor powered by a set of batteries. The power required to run the net winch is from the maximum load of the winch multiplied by its work time.

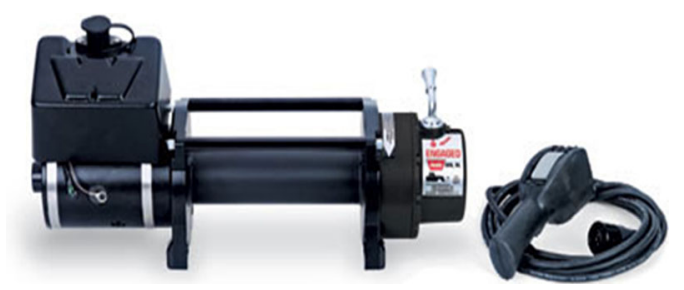

Fig. 5 Net winch 


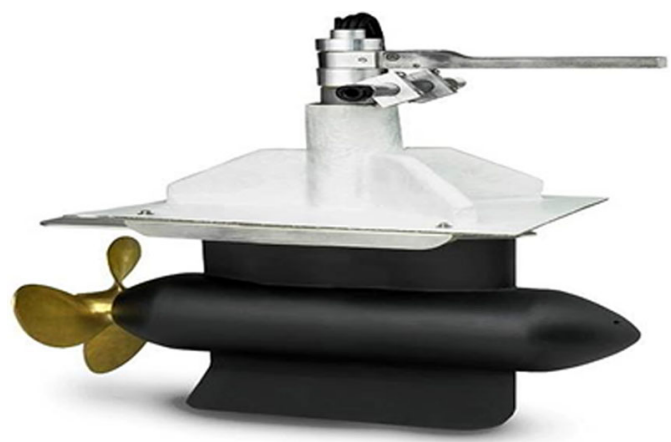

Fig. 6 Pod throttle

\subsubsection{Propulsion}

To move the platform to and from the fishing ground, two-pod propulsion system permanent magnet asynchronous motors, as shown in Fig. 6, are attached to the aft under each catamaran hull. The power needed to run the propulsion motors are obtained from the batteries installed in the platform. The specifications of the pod propeller are presented in Table 4.

The power required to operate the propulsion system of the catamaran platform is estimated from the total resistance of the vessel multiplied by the overall efficiency of the propulsion system, and the power to move the vessel is obtained from the multiplication of its speed and total resistance (Sohn et al. 2015).

Effective power to move the boat is as follows:

$P_{E}=V \times R_{T}$

or power required for boat propulsion:

$P_{E}=P_{B} \times \eta_{T}$

where $P_{E}$ is effective power, $V$ is speed of the vessel, $R_{T}$ is total resistance, $P_{B}$ is power at the gear, and $\eta_{T}$ is total efficiency.

Table 4 Pod throttle specifications

\begin{tabular}{ll}
\hline Model & UF80e \\
Output power(W) & 8000 \\
Input power(W) & 8690 \\
Efficiency(\%) & 92 \\
Voltage(V) & 48 \\
Current(A) & 178 \\
Weight(kg) & 40 \\
Motor type & Sensor-less AC motor \\
Suspension & A brazen rudder gland \\
\hline
\end{tabular}

Table 5 Power vs. speed using slender body method

\begin{tabular}{lr}
\hline Speed $(\mathrm{m} / \mathrm{s})$ & Power/W \\
\hline 0.51 & 34.890 \\
0.64 & 64.354 \\
0.77 & 106.183 \\
0.90 & 162.339 \\
1.03 & 235.696 \\
1.16 & 327.132 \\
1.29 & 443.956 \\
1.41 & 583.655 \\
1.54 & 752.114 \\
1.67 & 938.363 \\
1.80 & 1176.380 \\
1.93 & 1462.743 \\
2.06 & 1731.796 \\
2.19 & 2061.765 \\
2.32 & 2658.207 \\
2.44 & 2796.641 \\
2.57 & 3882.421 \\
2.70 & 4436.806 \\
2.83 & 4602.802 \\
2.96 & 6612.063 \\
3.09 & 8426.530 \\
\hline &
\end{tabular}

\subsubsection{Hull Resistance}

To determine the amount of power required by the vessel to be able to sail at a certain speed, we simulated the ship resistance using Maxsurf resistance software by using slender body method to analyze ship resistance. One of the parameters included in the simulation is $60 \%$ efficiency of the hull resistance. The results of this analysis will appear in the form of a "power vs. speed" figure.

\section{Results}

To determine the number of PV panels required to provide sufficient solar power to run all the equipment in the fishing platform and sail the platform to and from the fishing grounds, we estimate the power needed by each equipment and platform propulsion system.

Table 6 Power consumption for propulsion system

\begin{tabular}{lc}
\hline Speed(m/s) & 2.57 \\
Input current from PV panel(A) & 65 \\
Output current to motor(A) & 86.37 \\
Power consumption(Wh) & 3882 \\
\hline
\end{tabular}


Table 7 Battery pack for propulsion system

\begin{tabular}{ll}
\hline Type of battery & Lithium ion \\
\hline Nominal voltage(V) & 48 \\
Battery capacity(Ah) & 75 \\
Quantity & 2 \\
\hline
\end{tabular}

\subsection{Hull Resistance}

Based on the distance of the fishing grounds from the shore ( $5 \mathrm{mi}$ ); and the speed of the vessel $(5 \mathrm{kn})$. Table 5 presents the results of the power vs. speed analysis conducted by Maxsurf resistance software with slender body method.

\subsection{Power Consumption for Propulsion System}

The resistance data based on the vessel sailing speed and throttle specifications are used to determine the power needed by the vessel. The results of this calculation are reported in Table 6. The battery pack specifications are shown in Table 7.

\subsection{Power Consumption for Equipment}

Energy for lighting is estimated by summing up the power needed by each lamp multiplied by the operation time and the number of the lamps required. Results of the estimation are reported in Table 8 , and the battery pack specifications are shown in Table 9.

The power consumption for the net winch is estimated by summing up the power needed by each winch multiplied by the duration of the winch to be operated. The results of the power consumption for the net winches are shown in Table 10, and the battery pack specifications are presented in Table 11.

\subsection{PV Panel and Solar Charge Controller}

The energy needed for the vessel is obtained from the PV panels installed above the deck. As the vessel is operated only

Table 8 Power consumption estimation for lightings

\begin{tabular}{llrrl} 
Type of lamp & Power(W) & Quantity & $\begin{array}{l}\text { Operation } \\
\text { time(h) }\end{array}$ & $\begin{array}{l}\text { Total power } \\
\text { consumption(Wh) }\end{array}$ \\
\hline Fish collecting & 24 & 10 & 8 & 1920 \\
Working & 80 & 4 & 10 & 3200 \\
Crews' cabin & 10 & 4 & 8 & 320 \\
Total & & & & 5440 \\
\hline
\end{tabular}

Table 9 Specifications of battery pack for lighting

\begin{tabular}{lr}
\hline Type of battery & Lead acid \\
\hline Nominal voltage(V) & 24 \\
Battery capacity(Ah) & 250 \\
Quantity & 1 \\
\hline
\end{tabular}

at night, the PV panels are only installed at daytime; and are removed when the vessel is sailing to the fishing ground, thereby reducing the load of the propulsion system. The composition of PV panels is based on the available area on the deck of the vessel. Therefore, maximum power that can be produced depends on the available area. For this particular vessel, flexible monocrystalline PV panels are installed in combination with an MPPT type solar charge controller (Solbian 2017).

Total power required for propulsion and the vessel equipment is $24.68 \mathrm{kWh}$. If the charging time is assumed to be $8 \mathrm{~h}$, then the minimum number of PV panels needed is 20 , and the number of solar charger controller is 5 .

\section{Discussion}

The HDPE material used for the vessel construction is slightly more expensive than glass fiber reinforced polymer (GFRP). However, HDPE is recyclable and more durable than GFRP, and does not need to be built in series, because the production process is more or less similar to that of a metal boat.

As the vessel only operates at night, the PV panels are not necessarily installed on the vessel but can be installed on shore, thereby providing greater flexibility to the quantity of panels needed to supply a sufficient amount of energy to operate the vessel and its equipment.

The proposed solar-powered fishing platform is still in the experimental stage. Thus economical aspects have not been studied yet. However, considering the environmental and safety aspects, we can argue that the proposed platform made of HDPE has greater benefit compared with the traditional bamboo structure that uses fossil fuel to operate the fishing platform.

Table 10 Power consumption for net winch

\begin{tabular}{lllll}
\hline $\begin{array}{l}\text { Type of } \\
\text { winch }\end{array}$ & Power(W) & Quantity & $\begin{array}{l}\text { Operation } \\
\text { time(h) }\end{array}$ & $\begin{array}{l}\text { Total power } \\
\text { consumption(Wh) }\end{array}$ \\
\hline $\begin{array}{c}\text { Fish net } \\
\text { puller }\end{array}$ & 3840 & 2 & 2 & 15360 \\
\hline
\end{tabular}


Table 11 Specifications of battery pack for net winch

\begin{tabular}{lr} 
Type of battery & Lead acid \\
\hline Nominal voltage(V) & 24 \\
Battery capacity(Ah) & 200 \\
Quantity & 5 \\
\hline
\end{tabular}

\section{Conclusions}

The moveable catamaran fishing platform is more environmentally friendly than the traditional bamboo structure, because it uses solar energy instead of fossil fuel. A total of 20 PV panels are needed to operate the vessel when its speed is $5 \mathrm{kn}$, and the distance from the shore to the fishing ground is $5 \mathrm{mi}$.

Acknowledgements The authors are grateful to the Solar Boat 2016 Team in Universitas Indonesia for initiating the study and providing significant data and experience as well as to every party that supported the development of this research project.

Funding This study is funded by the PITTA Project Directorate of Research and Community Engagement, Universitas Indonesia No. 842/ UN2.R3.1/HKP.05.00/2017.

Open Access This article is distributed under the terms of the Creative Commons Attribution 4.0 International License (http:// creativecommons.org/licenses/by/4.0/), which permits unrestricted use, distribution, and reproduction in any medium, provided you give appropriate credit to the original author(s) and the source, provide a link to the Creative Commons license, and indicate if changes were made.

\section{References}

Aditia FR (2017) Design of solar powered underwater light for fishing platform (in Indonesian). Under-Graduate Project, Sepuluh Nopember Institute of Technology Surabaya. 50-58. http:// repository.its.ac.id/id/eprint/2943. Accessed 7 Mar 2017

Jamaluddin A, Utama IKAP, Aryawan WD, Widodo B (2012) Experimental investigations into the resistance components of symmetrical catamarans with variations in hull clearances and staggers. IJSCT 154(Part B):33-38. https://doi.org/10.3940/rina.ijsct.2012. b1.124

Michelino S (2010) Bagang or anchovy fishing platform. Photograph Collections. Quintin Lake. http://quintinlake.photoshelter.com. Accessed 3 Nov 2016
Mills E, Gengnagel T, Wollburg P (2014) Solar-LED alternatives to fuel-based lighting for night fishing. ESD 21(1):30-41. https:// doi.org/10.1016/j.esd.2014.04.006

Nursal RS, Nordin NI, Mohammad M, Hamid MA, Awang MN, Ariffin AA (2017) Investigation on resistance effects through towing test and CFD analysis on catamaran boat hull form. J Eng Appl Sci 12(4):1334-1343

Olaniyan RF (2015) Fishing methods and their implications for a sustainable environment. Fish Aquac J 6(3):1-3. https://doi.org/10.4172/ 2150-3508.1000139

Regnu Rama Das JR (2017) Motorized winch for Chinese fishing net. Science for Equity, Empowerment and Development Division, Department of Science and Technology Government of India. http://dsttara.in/InnerPages/Technology_Details.aspx. Accessed 3 Nov 2016

Sadhotomo B (2007) Size distribution of pelagic fishes in the Java Sea by means of target strength analysis. IFRJ 13(2):81-99. https://doi.org/ 10.15578/ifrj.13.2.2007.81-99

Setyawan D, Utama IKAP, Murdijanto, Sugiarso A, Jamaluddin A (2010) Development of catamaran fishing vessel. IPTEK 21(4):167-173. https://doi.org/10.12962/j20882033.v21i4.90

Shen CS, Huang HJ (2012) Design of LED fish lighting attractors using horizontal/vertical LIDC mapping method. J Opt Soc Am 20(24): 26135-26146. https://doi.org/10.1364/OE.20.026135

Sohn SI, Park DH, Lee YS, Oh IK (2013) Hull separation optimization of catamaran unmanned surface vehicle powered with hydrogen fuel cell. IJMCPECE 6(3):302-306

Sohn SI, Park DH, Lee YS, Oh IK (2015) Design of a fuel-cell-powered catamaran type unmanned surface vehicle. IEEE OES 40(2):388396. https://doi.org/10.1109/JOE.2014.2315889

Solbian (2017) Flexible solar panel. Product brochure. https://www. solbian.eu/en/4-flexible-solar-panels. Accessed 3 Nov 2016

Solomon OO (2016) Fishing with light: ecological consequences for coastal habitats. IJFAS 4(2):474-483. https://doi.org/10.1002/aqc. 3270050305

Sudirman, Mallawa A (2004) Fish catching techniques (in Indonesian). Rineka Cipta, Jakarta, 164-168

Susanto A, Irnawati R, Mustahal, Syabana MA (2017) Fishing efficiency of LED lamps for fixed lift net fisheries in Banten Bay Indonesia. Turk J Fish Aquat Sci 17:283-291. https://doi.org/10.4194/13032712-v17_2_07

Tideman B (2015) 10 reasons to choose a HDPE boat. Tideman Boat Company Profile. https://tidemanboats.com/hdpe-the-new-plastic10-reasons-to-choose-a-hdpe-workboat/. Accessed 3 Nov 2016

Utama IKAP, Santosa I, Chao RM, Nasiruddin RM (2013) New concept of solar- powered catamaran fishing vessel. Proceedings of the 7th International Conference on Asian and Pacific Coasts, 903-909.

Victron Energy (2017) Solar charge controller. Product brochure. https:// www.victronenergy.com/solar-charge-controllers. Accessed 5 Nov 2016 